\title{
PERANCANGAN BUKU "KOMUNIKASI DALAM ISYARAT" SEBAGAI MEDIA PENGENALAN HURUF HIJAIYAH UNTUK ANAK TUNARUNGU BERBASIS ILUSTRASI
}

\author{
Mahendra Wibawa ${ }^{1 *}$, Anita Wulan Suci²* \\ Program Studi Desain Komunikasi Visual \\ Sekolah Tinggi Informatika dan Komputer Indonesia Malang \\ Jl. Raya Tidar No. 100, Karangbesuki, Kecamatan Sukun, Kota Malang, Kode Pos 65146 \\ Jawa Timur, Indonesia \\ Email: mahendra@stiki.ac.id,nitaaws@gmail.com
}

\begin{abstract}
Abstrak
Anak tunarungu merupakan anak dengan keterbatasan pendengaran yang kurang berfungsi dengan baik maupun tidak sama sekali. Anak tunarungu berkomunikasi dengan cara menggunakan kombinasi pola gerakan tertentu, juga disertai dengan ekspresi wajah dan gerak mulut yang bisa dibaca secara visual melalui indera penglihatan. Bagi anak tunarungu muslim, keterbatasan lainnya yaitu sulit memahani dan menghafal huruf huruf hijaiyah. Salah satu faktor penyebab sulit memahami huruf hijaiyah adalah keterbatasan media belajar Al-Qur'an khusus untuk anak tunarungu. Media yang selama ini digunakan untuk belajar huruf hijaiyah adalah buku Iqro', kelemahan pada buku ini karena di dalamnya tidak ada cara membaca Al-Qur'an melalui huruf abjad maupun isyarat hijaiyah. Berawal dari keterbatasan anak tunarungu dan kelemahan pada buku Iqro', muncullah ide merancang buku ilustrasi pengenalan huruf hijaiyah untuk anak tunarungu. Media yang dirancang merupakan buku berjudul "Komunikasi dalam Isyarat" berukuran $20 \mathrm{~cm}$ x 20 dan memiliki 53 halaman, cover buku menggunakan soft cover, dan lembaran halaman menggunakan bahan kertas HVS $100 \mathrm{~g}$. Buku ini berisi tentang materi huruf hijaiyah, isyarat hijaiyah, latihan soal, soal evaluasi, dan potongan puzzle yang diletakkan ke dalam puzzle container.
\end{abstract}

Kata Kunci: buku, ilustrasi, tunarungu, isyarat, hijaiyah.

\begin{abstract}
Deaf childrens are children with hearing limitation that can be fully or partial hearing function problems. Deaf childrens can communicate using movement pattern combinations (sign language), accompanied by face expression dan lips reading that can be studied using eyesight. For moslem deaf children, they have limitation on understanding and memorizing hijaiyah alphabets. One of the factors that make it hard to learn is the learning media limitation on Al-Quran for deaf childrens. Media that usually use to learn hijaiyah alphabets is Iqro books, the weak side of this book is there's no procedure on how to pronounce Al-quran from letters of alphabets or in hijaiyah sign. Start from this limitation on deaf childrens and iqro book's weaknesses, the idea to designing illustration book of hijaiyah alphabet introduction for deaf children was emerge. The media for the design is a book titled "Komunikasi dalam Isyarat" ("Communicate in sign") in $20 \times 20 \mathrm{~cm}$ size with 53 pages and soft covered, the content pages will be in HVS $100 \mathrm{~g}$ paper. This book will contain hijaiyah alphabets, hijaiyah sign, exercises, evaluation test, and puzzle pieces that will be included in puzzle container.
\end{abstract}

Keywords: book, illustration deaf, sign, hijaiyah.

\section{PENDAHULUAN}

Al-Qur'an merupakan kitab suci umat Islam yang wajib untuk dibaca, dipahami, dan diamalkan oleh umat Islam apapun keadaannya baik orang normal maupun orang dengan penyandang disabilitas. Proses pembelajaran Al-Qur'an bagi umat Islam yaitu umat Islam harus mempelajari huruf hijaiyah terlebih dahulu agar mampu membaca Al-Qur'an dengan baik dan benar. Metode mempelajari Al-Quran terutama mempelajari huruf hijaiyah tiap orang berbeda-beda sesuai dengan kemampuan masing-masing, hal ini terjadi pula kepada orang-orang normal dan orang penyandang disabilitas.

Penyandang disabilitas terbagi menjadi 4 jenis (Wisnuwardani, 2019) diantaranya yaitu disabilitas fisik, disabilitas intelektual, disabilitas mental, dan disabilitas sensori. Beberapa jenis disabilitas ada yang memiliki keterbatasan dalam mempelajari beberapa hal salah satunya yaitu mempelajari huruf hijaiyah seperti 
orang normal pada umumnya. Metode yang digunakan mempelajari huruf hijaiyah juga disesuaikan dengan kemampuan yang dimiliki oleh penyandang disabilitas tersebut. Tujuan dari penggunaan metode pembelajaran sesuai dengan kemampuan masing-masing penyandang disabilitas yaitu untuk memudahkan penyandang disabilitas untuk belajar Al-Qur'an.

Penyandang disabilitas yang menggunakan metode berkomunikasi khusus untuk berkomunikasi salah satunya adalah tunarungu. Tunarungu memiliki gangguan pada pendengarannya sehingga tidak dapat mendengar bunyi dengan sempurna atau bahkan tidak dapat mendengar sama sekali. Tunarungu dibedakan menjadi dua yaitu, tuli (tunarungu) atau kurang dengar (hard of hearing). Tunarungu merupakan seseorang yang pendengarannya mengalami kerusakan dalam level berat sehingga pendengarannya tidak berfungsi lagi, sedangkan kurang dengar merupakan seseorang dengan indera pendengarannya mengalami kerusakan namun masih dapat berfungsi untuk mendengarkan, baik dengan maupun tidak menggunakan alat bantu dengar (hearing aids) (Setywan et al., 2017).

Penyandang tunarungu menggunakan bahasa isyarat sebagai jalur utama komunikasi yang diakibatkan karena keterbatasan mereka dalan menerima pesan suara. Mereka memanfaatkan gerak tubuh seperti membuat kombinasi pola gerakan tertentu dan juga disertai dengan ekspresi wajah dan gerak mulut yang bisa dibaca secara visual melalui indera penglihatan yang masih berfungsi dengan baik. Indonesia mengenal dua sistem bahasa isyarat yakni Sistem Bahasa Isyarat Indonesia (SIBI) dan Bahasa Isyarat Indonesia (BISINDO). SIBI merupakan bahasa isyarat yang hanya dapat digunakan sebagai bahasa isyarat di Sekolah dan tidak dapat dipergunakan sebagai bahasa komunikasi sehari-hari karena penerapan bahasa terlalu baku sehingga tidak sesuai dengan aspirasi dan nurani tunarungu. Penyandang tunarungu yang kesulitan menggunakan sistem SIBI cenderung memilih sistem BISINDO sebagai bahasa komunikasi sehari-hari. Mereka beralasan bahwa BISINDO merupakan bahasa isyarat alami Indonesia yang dapat digunakan dalam pergaulan isyarat tunarungu sehari-hari (Gumelar et al., 2018).

Pembelajaran baca Al-Qur'an untuk anak tunarungu di SLB A, B, D Negeri Kedungkandang Kota Malang menggunakan metode hafalan, kombinasi bahasa isyarat, membaca gerak bibir (oral) dan menggunakan sistem BISINDO, metode ini digunakan untuk mengajar seluruh kelas dari SD hingga SMA serta tidak ada perbedaan metode pembelajaran baca Al-Qur'an.
Materi pembelajaran agama Islam yang diberikan untuk siswa SDLB bagian tunarungu yaitu hafalan surat-surat pendek Al-Qur'an dan pengenalan huruf hijaiyah beserta harokat-harokatnya. Metode pembelajaran baca Al-Qur'an ini melalui media buku mengaji Iqro saja. Anak tunarungu tidak hanya memiliki keterbatasan dalam pendengaran saja namun juga keterbatasan memahami tulisan yang terlalu panjang dan ilustrasi perangsang imajinatif, sehingga guru agama pada SLB tersebut harus merangkum kalimat yang ada pada buku menjadi lebih padat dan jelas, serta menghindari media yang terlalu imajinatif karena anak tunarungu membutuhkan gambar nyata sesuai dengan kehidupan sehari-hari. Media pembelajaran yang kurang mendukung untuk penyandang tunarungu membuat para guru SLB A, B, D Negeri Kedungkandang memaksimalkan pembelajaran dengan media yang digunakan oleh orang normal.

Perancangan media pembelajaran baca Al-Qur'an bagi anak tunarungu ditujukan untuk anak berusia $7-12$ tahun. Anak tunarungu pada usia ini memiliki daya tangkap berfikir yang rendah untuk menerima suatu informasi terutama materi pelajaran agama Islam, mereka masih mengalami kesusahan untuk mengenal dan memahami huruf hijaiyah di Sekolah. Media yang akan digunakan untuk menyampaikan materi pembelajaran adalah buku ilustrasi yang berisi pengenalan huruf hijaiyah untuk anak tunarungu, secara visual media memerlukan warna cerah sebagai penarik perhatian anak tunarungu.

Siswa yang belajar menggunakan media buku penuh ilustrasi menunjukkan perkembangan signifikan dalam memahami cerita, begitupun buku ilustrasi pengenalan huruf hijaiyah untuk anak tunarungu ini. Media buku mampu memberi manfaat kepada anak-anak karena dapat merangsang aspek motorik anak-anak. Perancangan buku pembelajaran baca Al-Qur'an anak tunarungu ini menggunakan pendekatan bahasa isyarat BISINDO, belajar sambil bermain, juga ikut serta peran guru maupun orang tua dalam membimbing proses belajar anak tunarungu agar mampu memahami isi AlQur'an dengan baik. Penerapan bahasa isyarat ini menampilkan ilustrasi visual pergerakan jari pada tiap huruf hijaiyah dan memberi beberapa soal menyelaraskan antara huruf hijaiyah dengan abjad Indonesia guna meningkatkan daya ingat anak tunarungu tersebut. Media buku ilustrasi ini dapat menambah daya tarik serta meningkatkan gairah belajar huruf hijaiyah untuk anak tunarungu. 


\section{KAJIAN TEORI}

\section{Huruf Hijaiyah}

Huruf arab merupakan huruf hijaiyah. Huruf hijaiyah adalah kumpulan huruf-huruf arab yang berjumlah 30 huruf. Huruf-huruf inilah yang terpakai dalam AlQur'an dan dikenal pada masa sekarang (Huda, 2019), namun menurut KBBI (Kamus Besar Bahasa Indonesia) hijaiah merupakan huruf Arab (dari alif sampai ya). Huruf hijaiyah adalah sesuatu yang wajib diketahui oleh semua umat Islam (Ikbal, 2021). Diluar posisinya sebagai unit terkecil dalam bahasa Arab, huruf hijaiyah tentu saja syarat awak seseorang dapat membaca Al-Quran. Bahkan mengenal huruf-huruf hijaiyah adalah pelajaran yang paling awal diajarkan ketika seseorang baru belajar tentang agama Islam.

Terdapat tiga macam perhitungan berbeda terkait dengan jumlah huruf hijaiyah yaitu 28, 29 dan 30 . Namun, pada hakikatnya ketiganya sebenarnya hanya didasarkan pada menghitung huruf tertentu sebagai satu huruf yang mandiri, atau memasukkannya dalam bagian huruf yang lain. Jika mengambil huruf terbanyak, maka jumlah keseluruhan adalah 30 huruf, dengan rincian sebagai berikut:

$$
\begin{aligned}
& \text { ا ب ت ث ج ح خد ذ ر ز س ش ص ض طظ ع غ ف ق ك ل }
\end{aligned}
$$

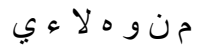

Gambar 1. Huruf Hijaiyah

Dari pengertian di atas, dapat disimpulkan huruf hijaiyah merupakan huruf-huruf dasar bahasa arab yang berjumlah 30 huruf (alif sampai ya) Yang wajib dipelajari dan dipahami oleh seluruh umat muslim yang ada di dunia.

\section{Anak}

Anak usia 7 - 12 tahun merupakan fase dimana sedang mengalami perkembangan pada motorik dan kognitifnya (Sesdiawan, 2013). Media pembelajaran terhadap anak merupakan perantara dalam pemberian informasi untuk menunjang perkembangan motorik dan kognitif anak. Media yang digunakan harus sesuai dengan karakteristik anak usia $7-12$ tahun. Karena proses belajar tiap fase umur adalah berbeda beda. Motorik anak umur 7 - 12 tahun sudah lebih dapat diorganisir. Kognitifnya pun sudah lebih logis dan sedang belajar untuk memahami dirinya sendiri.

\section{Tunarungu}

Tuli, tunarungu, atau gangguan dengar dalam kedokteran adalah kondisi fisik yang ditandai dengan penurunan atau ketidakmampuan seseorang untuk mendengarkan suara (Huda, 2019). Tuli dalam kedokteran dibagi atas 3 jenis, diantaranya: a). Tuli/ Gangguan Dengar Konduktif adalah gangguan dengar yang disebabkan kelainan di telinga bagian luar dan/atau telinga bagian tengah, sedangkan saraf pendengarannya masih baik, dapat terjadi pada orang dengan infeksi telinga tengah, infeksi telinga luar atau adanya serumen di liang telinga, b). Tuli/Gangguan Dengar Saraf atau Sensorineural yaitu gangguan dengar akibat kerusakan saraf pendengaran, meskipun tidak ada gangguan di telinga bagian luar atau tengah, dan c). Tuli/Gangguan Dengar Campuran yaitu gangguan yang merupakan campuran kedua jenis gangguan dengar di atas, selain mengalami kelainan di telinga bagian luar dan tengah juga mengalami gangguan pada saraf pendengaran.

\section{Bahasa Isyarat}

Bahasa isyarat merupakan salah satu media komunikasi yang dilakukan oleh teman, orang tua dan orang sekitar dengan penyandang tunarungu (Yulia, 2015). Tunarungu di Indonesia memiliki dua bahasa isyarat yang digunakan, yaitu SIBI dan BISINDO.

\section{1). SIBI}

Winarsih (Gumelar et al., 2018) menjelaskan SIBI merupakan bahasa isyarat yang diciptakan oleh Alm. Anton Widyatmoko mantan kepala sekolah SLB/B Widya Bakti Semarang bekerjasama dengan mantan kepala sekolah SLB/B di Jakarta dan Surabaya. SIBI telah memiliki kamus yang diterbitkan oleh pemerintah dan disebarluaskan melalui sekolah-sekolah khususnya SLB/B untuk Tuli di Indonesia sejak tahun 2001. Keberadaan SIBI begitu populer di sekolah-sekolah SLB/B di Indonesia. "Pihak sekolah dan juga para guru menggunakan SIBI sebagai bahasa pengantar materi pembelajaran pada siswa Tuli”.

\section{2). BISINDO}

Basindo merupakan bahasa isyarat alami budaya asli Indonesia yang dengan mudah dapat digunakan dalam pergaulan isyarat Tuli sehari-hari (Gumelar et al., 2018). Bisindo merupakan bahasa isyarat yang dipelajari secara alami oleh Tuli sehingga Bisindo seperti halnya bahasa daerah dan memiliki keunikan di tiap daerah. Kecepatan dan kepraktisannya membuat tuli lebih mudah memahami meski tidak mengikuti aturan bahasa Indonesia sebagaimana yang digunakan SIBI. Bahasa Isyarat yang digunakan untuk belajar huruf hijaiyah dari Alif Hingga Ya bersumber dari Pondok Pesantren Putra dan putri Khusus Tunarungu Madrasah Tuli "Darul A'Shom" yang terletak di kota Bantul, Yogyakarta dan yayasan "The Little Hijabi Home Schooling" yang terletak di Kota Bekasi. Kedua yayasan tersebut merupakan yayasan yang sangat 


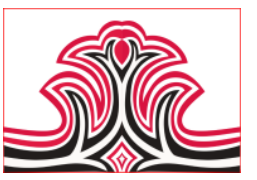

memiliki kepedulian kepada anak tunarungu. Kepedulian yang sangat nampak yaitu memperjuangkan hak-hak tunarungu agar mendapat akses belajar menggunakan Bahasa isyarat, baik Bisindo untuk berkomunikasi tunarungu dengan lawan bicaranya tiap hari dan juga menggunakan Bahasa isyarat hijaiyah digunakan untuk belajar Al-Qur'an. Pondok Pesantren "Darul A'Shom" dan yayasan "The Little Hijab Home Schooling" memiliki panduan belajar huruf hijaiyah menggunakan bahasa isyarat yang sama dari Arab Saudi, hal ini dapat menjadi acuan sumber terpercaya untuk belajar huruf hijaiyah melalui bahasa isyarat.

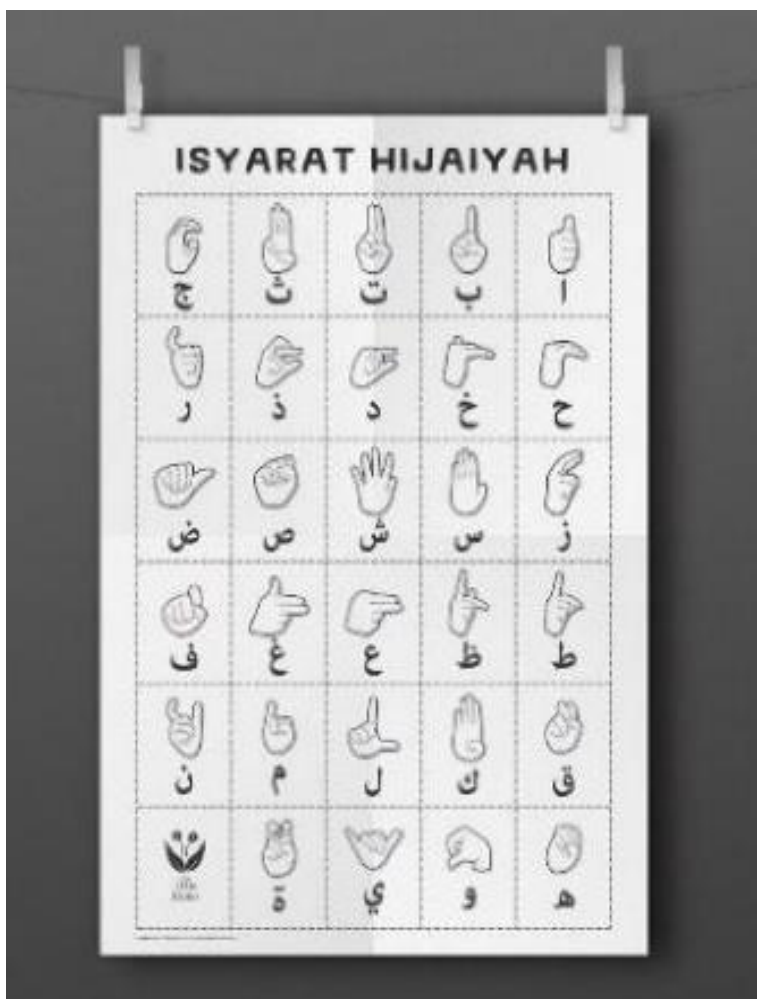

Gambar 2. Poster Isyarat Hijaiyah pada laman facebook "The Little Hijab Homeschooling",

(The Little Hijabi Homeschooling, 2020)
Gorga : Jurnal Seni Rupa

Volume 10 Nomor 01 Januari-Juni 2021

p-ISSN: 2301-5942 | e-ISSN: 2580-2380

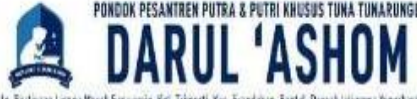

Bahasa Isyarat Hijaiyah
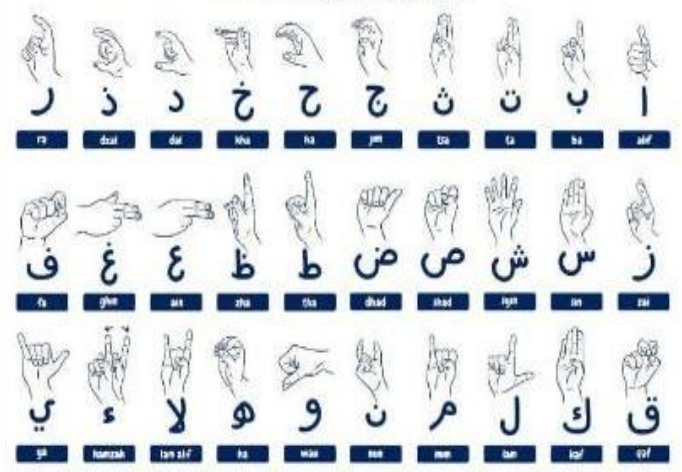

Gambar 3. Poster Bahasa Isyarat Hijaiyah pada laman facebook Darul A'Shom

(Darulashom, 2020)

\section{METODE PENELITIAN}

Perancangan ini menggunakan metode yang dikembangkan oleh Sanyoto. Adapun dalam hal perancangan dibutuhkan penggalian data untuk mendapatkan informasi tentang kemampuan anak tunarungu dalam membaca huruf hijaiyah.

\section{Sumber Data}

Sumber data primer didapatkan dari dua metode yakni: a). Observasi terhadap kegiatan pembelajaran Agama Islam di kelas 4, 5 dan 6 SDLB A, B, D Kedungkandang Malang, dan b). Wawancara terhadap dua narasumber guru agama Islam, yaitu Ibu Rusmiati dan Ibu Ida yang dilaksanakan di kantor guru dan kelas tunarungu SDLB A, B, D Kedungkandang Malang. Sumber data sekunder didapatkan dari berbagai data pendukung yang didapatkan melalui jurnal, buku dan publikasi lainnya

\section{Analisis Data}

Analisis yang akan digunakan dalam penelitian ini menggunakan metode analisa data $5 \mathrm{~W}+1 \mathrm{H}$. Analisa data $5 \mathrm{~W}+1 \mathrm{H}$ (What, Who, When, Where, Why, How). Metode analisis ini dipilih karena dalam perancangan ini dibutuhkan informasi yang secara deskriptif mampu memberikan gambaran yang lengkap sebagai dasar panduan perancangan buku buku ilustrasi pengenalan huruf hijaiyah untuk anak tunarungu ditujukan bagi siswa tunarungu kelas $1-6$ di SDLB A, B, D Kedungkandang Malang. 


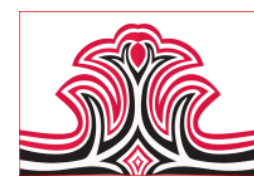

3. Metode Perancangan

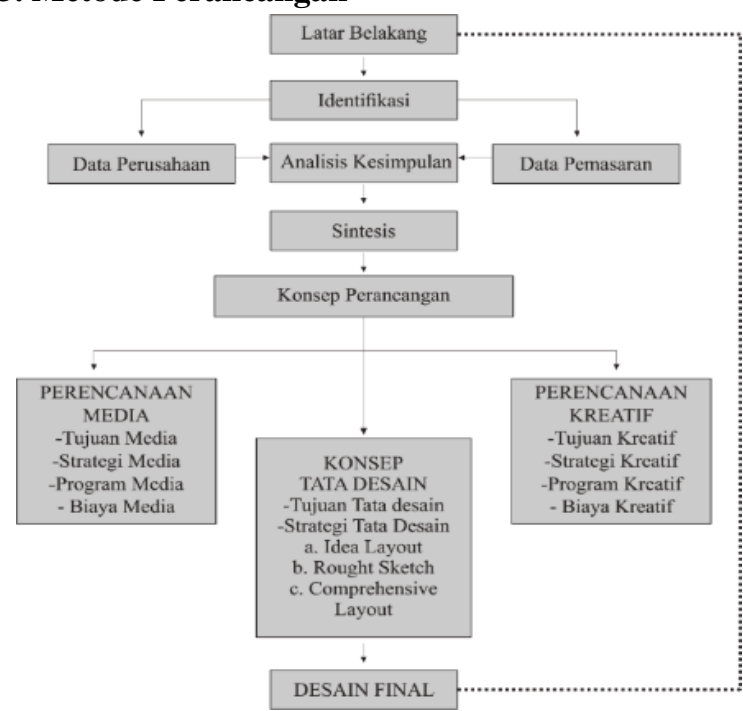

Gambar 4. Poster Bahasa Isyarat Hijaiyah pada laman facebook Darul A'Shom

(Darulashom, 2020)

Gambar 4 merupakan metode perancangan milik Sadjiman Ebdi Sanyoto (Sanyoto, 2006) yang digunakan sebagai metode dalam merancang buku pengenalan huruf hijaiyah untuk anak tunarungu, dengan penyesuaian pada beberapa tahap sesuai kebutuhan perancang.

\section{1). Tahapan Perancangan}

\section{(1). Perencanaan Media}

Komponen perencanaan pada perancangan buku ilustrasi pengenalan huruf hijaiyah untuk anak tunarungu ini hanya mengambil beberapa isi, yaitu tujuan media dan strategi media. Tujuan Media, buku ilustrasi pengenalan huruf hijaiyah untuk anak tunarungu ini dirancang untuk membantu anak tunarungu agar lebih mudah memahami huruf hijaiyah, selain itu buku ini juga dirancang untuk membantu memudahkan guru serta orang tua mendampingi anak tunarungu dalam proses belajar memahami huruf hijaiyah. Strategi Media, buku ilustrasi pengenalan huruf hijaiyah ditujukan untuk siswa tunarungu SDLB Kedungkandang Malang kelas $1-6$. Media buku ilustrasi ini memuat tentang pembahasan materi dan soal-soal tentang huruf hijaiyah, bahasa isyarat berupa gerakan jari tangan, dan huruf latin.

\section{(2). Perencanaan Kreatif}

Komponen perencanaan pada perancangan buku ilustrasi pengenalan huruf hijaiah untuk anak tunarungu ini hanya mengambil beberapa isi, yaitu tujuan kreatif dan strategi kreatif. Tujuan Kreatif, tujuan kreatif dari perancangan ini adalah untuk membantu anak tunarungu muslim agar lebih mudah memahami huruf hijaiyah dengan sentuhan desain ilustrasi pelajaran
Gorga : Jurnal Seni Rupa

Volume 10 Nomor 01 Januari-Juni 2021

p-ISSN: 2301-5942 | e-ISSN: 2580-2380

berwarna untuk menarik perhatian serta meningkatkan minat belajar anak-anak tunarungu. Buku ilustrasi ini juga mampu meringankan guru serta orang tua dalam menyampaikan materi pengenalan huruf hijaiyah kepada anak tunarungu. Strategi kreatif, buku ilustrasi pengenalan huruf hijaiyah ditujukan untuk siswa tunarungu SDLB Kedungkandang Malang kelas $1-6$. Isi dari buku tersebut membahas tentang materi huruf hijaiyah yang didampingi dengan bahasa isyarat berupa gerakan jari, dan huruf abjad. Materi bahasa isyarat gerakan jari di dalam buku terdapat panduan cara melengkuk beberapa bagian jari tangan kanan untuk membentuk suatu isyarat huruf hijaiyah. Panduan cara melengkuk beberapa bagian jari digambarkan dengan ilustrasi kartun gerakan jari tangan kanan, ilustasi buku pelajaran gerakan tangan berfungsi sebagai pemandu anak tunarungu untuk mencapai bahasa isyarat huruf hijaiyah sesuai dengan kemampuan anak tunarungu. Buku ilustrasi pengenalan huruf hijaiyah untuk anak tunarungu didesain memiliki warna yang cerah dibagian ilustrasi kartun gerakan tangan hingga layout media, dan memperhatikan tingkat keterbacaan disetiap kata maupun kalimatnya.

\section{(3). Konsep Tata Desain}

\section{a. Sketsa}

Pada tahap ini perancang membuat sebuah sketsa yang terbagi menjadi 2 fungsi, yaitu sketsa untuk desain layout dan sketsa untuk desain ilustrasi. Sketsa desain layout digambarkan sebuah salju yang turun yang terus menerus hingga muncul sebuah tumpukan salju, desain layout berfungsi sebagai background halaman buku yang berisi materi pengenalan huruf hijaiyah beserta latihan soalnya. Sketsa desain ilustrasi digunakan untuk menggambar ilustrasi gerakan tangan kanan yang menunjukkan isyarat hijaiyah, hal ini berfungsi untuk memastikan tingkat keterbacaan isyarat hijaiyah dan detail lekukan tangan sudah jelas atau belum. Hasil sketsa secara menyeluruh yang telah digambar oleh perancang yaitu, Cover buku ilustrasi terdapat tipografi judul buku, kalimat keterangan target audience, serta pattern sebagai background cover buku. Isi di dalam buku memiliki beberapa konten, yaitu materi pengenalan huruf hijaiyah dari alif hingga ya, pengenalan isyarat hijaiyah, dan soal - soal seputar materi tersebut untuk menguji seberapa jauh pemahaman anak tunarungu belajar menggunakan buku ini. 


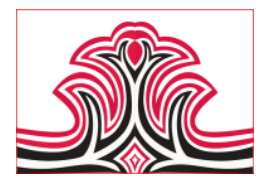

b. Sketsa Cover

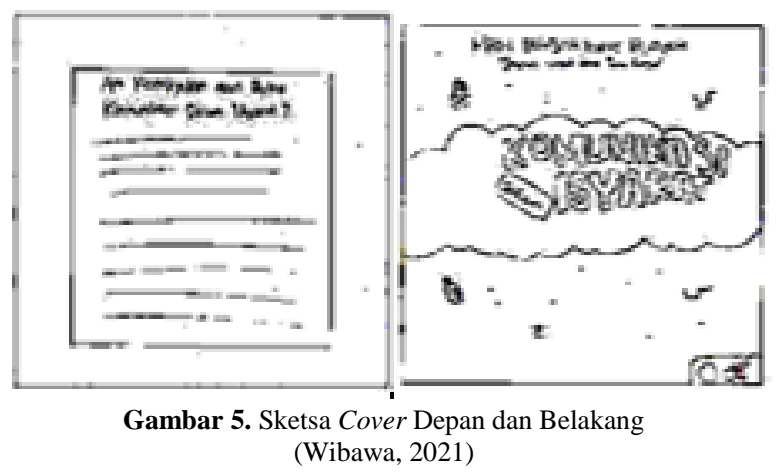

a). Sketsa Pemahaman Materi

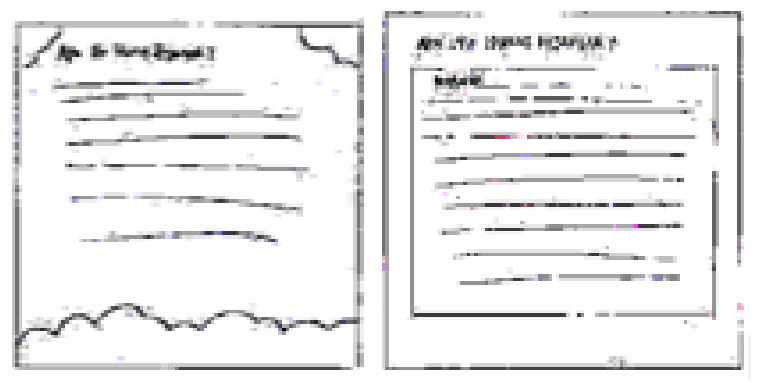

Gambar 6. Sketsa Pemahaman Materi (Wibawa, 2021)

b). Sketsa Materi Pembelajaran

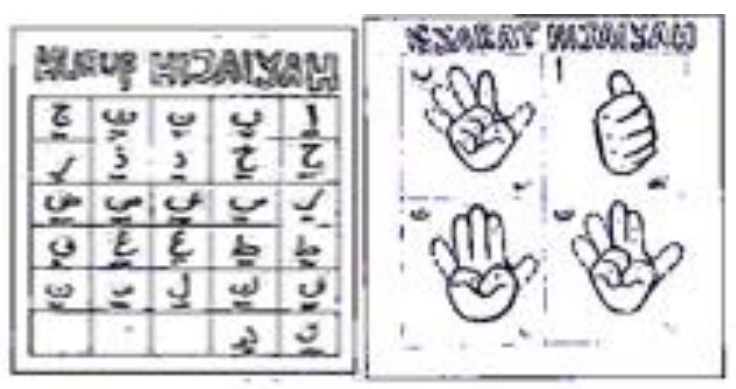

Gambar 7. Sketsa Materi Pembelajaran (Wibawa, 2021)

\section{c). Sketsa Panduan Latihan Soal}

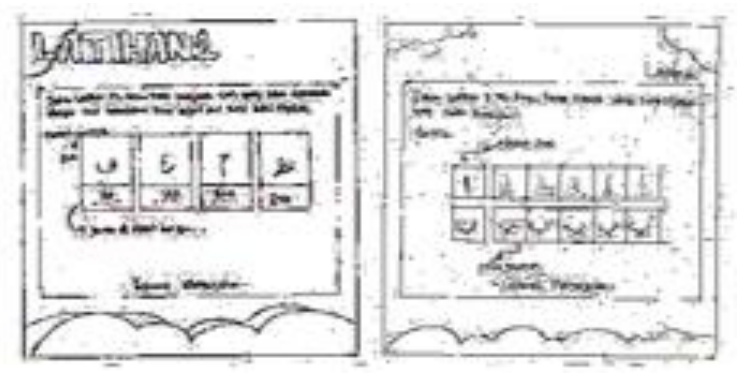

Gambar 8. Sketsa Panduan Latihan Soal (Wibawa, 2021)
Gorga : Jurnal Seni Rupa

Volume 10 Nomor 01 Januari-Juni 2021 p-ISSN: 2301-5942 | e-ISSN: 2580-2380

d). Sketsa Latihan Soal

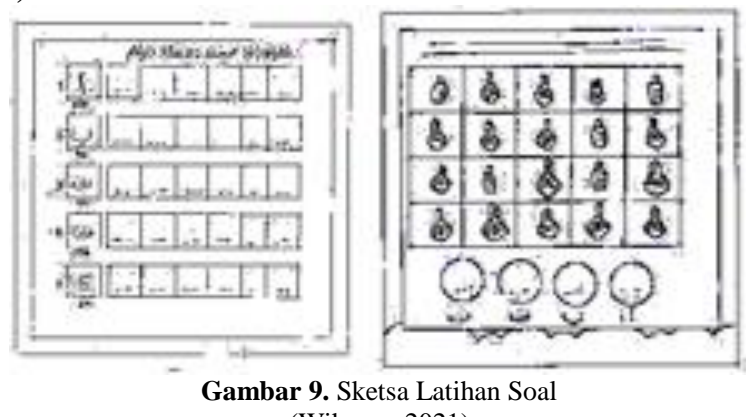
(Wibawa, 2021)

e). Sketsa Lembar Jeda

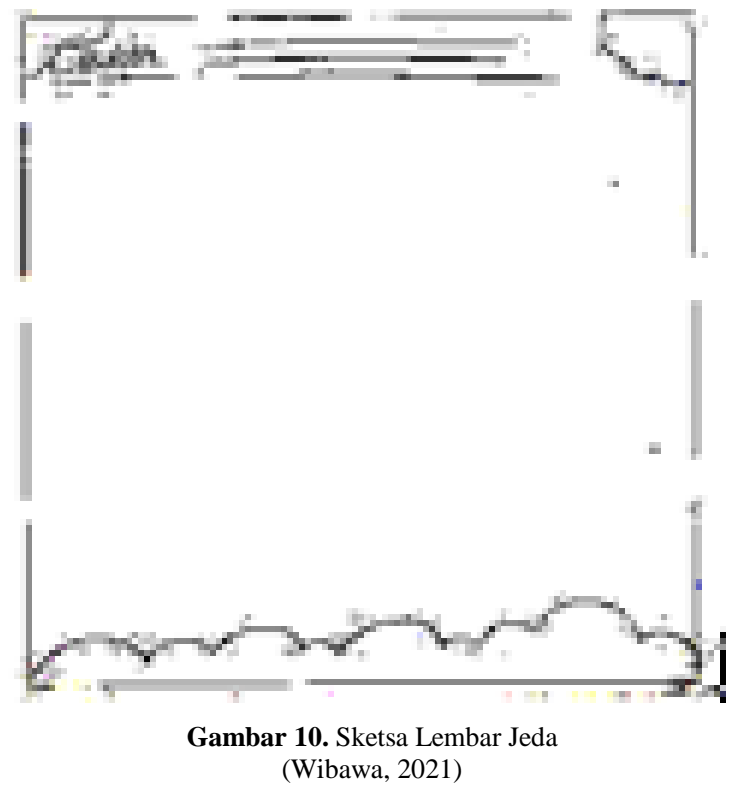

f). Sketsa Lembar Evaluasi

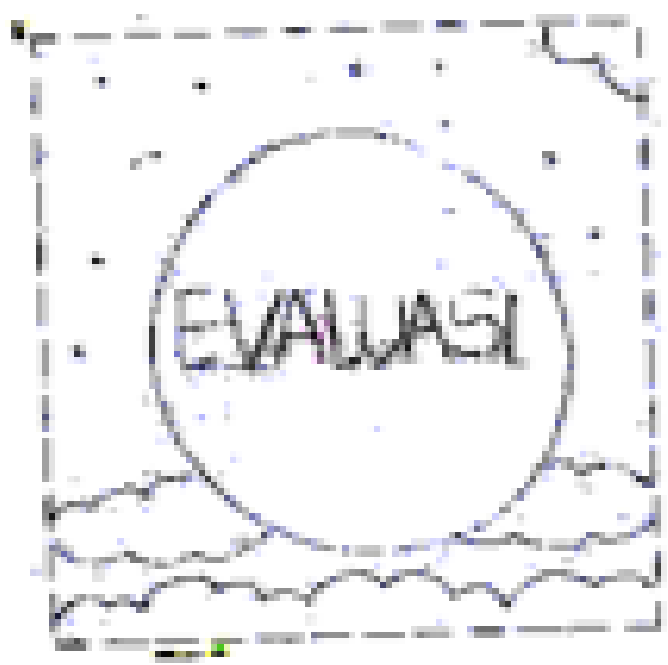

Gambar 11. Sketsa Lembar Evaluasi (Wibawa, 2021) 


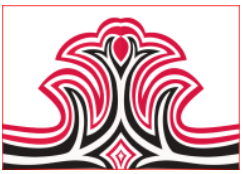

g). Sketsa Penutup dan Biodata Penulis
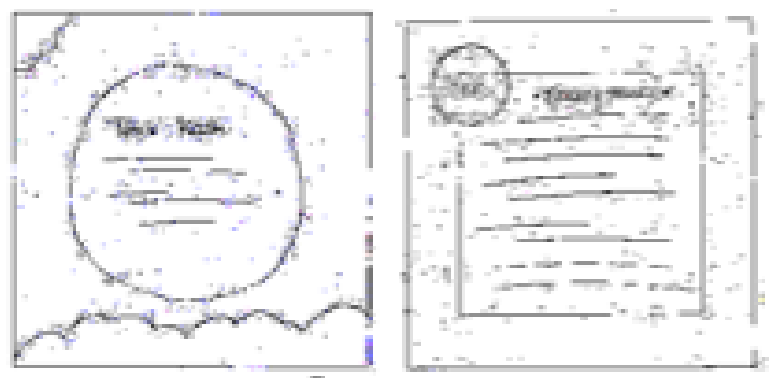

Gambar 12. Sketsa Penutup dan Biodata Penulis (Wibawa, 2021)

\section{HASIL DAN PEMBAHASAN}

\section{Hasil}

\section{1). Konsep Perancangan}

Perancangan buku ilustrasi pengenalan huruf hijaiyah untuk anak tunarungu berjudul "Komunikasi dalam Isyarat" memiliki konsep perancangan ketika di digitalisasikan, diantaranya:

\section{(1). Layout}

Layout buku "Komunikasi dalam Isyarat" berkonsep salju berwarna putih yang menumpuk di daratan yang bermakna kesejukan dan keceriaan (Sasongko et al., 2020). Kotak - kotak pada tiap halaman digunakan sebagai letak tulisan, baik materi maupun soal - soal yang disampaikan sesuai tema pembelajaran yang sudah dikonsep sebelumnya.

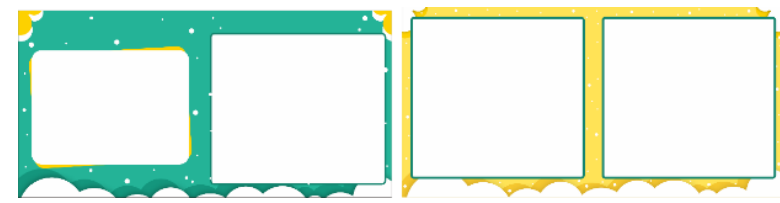

Gambar 13. Layout Buku "Komunikasi Dalam Isyarat" (Wibawa, 2021)

\section{(2). Warna}

Warna yang digunakan untuk menghidupkan layout buku "Komunikasi dalam Isyarat" adalah kombinasi warna hijau dan kuning. Kombinasi warna cerah ini mengungkapkan kebahagiaan, kehangatan, keceriaan, semangat, optimis, dan kepandaian (Monica \& Luzar, 2011). Warna hijau dan kuning merupakan warna yang cerah sehingga dapat menarik perhatian anak usia 7 12 tahun ketika belajar. Warna merah merupakan warna cerah dan terlihat sangat menonjol dari beberapa warna yang diterapkan (emphasis) pada buku "Komunikasi dalam Isyarat" ini. Warna merah yang sangat menonjol ini digunakan sebagai warna anak panah yang mengarahkan pembaca untuk menulis jawaban sesuai pada tempatnya di halaman panduan mengerjakan latihan soal. Warna hitam dan putih merupakan warna netral, warna putih digunakan
Gorga : Jurnal Seni Rupa

Volume 10 Nomor 01 Januari-Juni 2021

p-ISSN: 2301-5942 | e-ISSN: 2580-2380

sebagai background halaman buku untuk melindungi materi pelajaran berupa gambar dan tulisan dapat terlihat jelas dan tidak terganggu oleh warna-warna lainnya, dan warna hitam digunakan untuk kalimat pada soal-soal evaluasi.

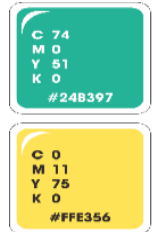

FFE356
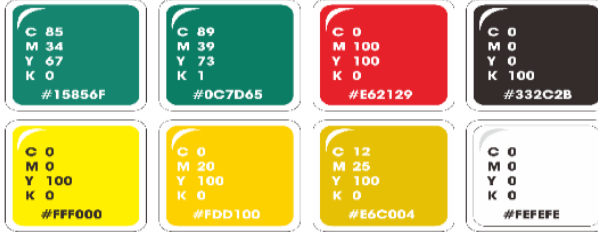

Gambar 14. Warna Layout Buku (Wibawa, 2021)
Warna yang digunakan untuk mewarnai ilustrasi gerakan tangan isyarat hijaiyah merupakan warna dominan cream ke coklat. Pemilihan warna ini disesuaikan dengan skin tone mayoritas masyarakat Indonesia yaitu sawo matang.

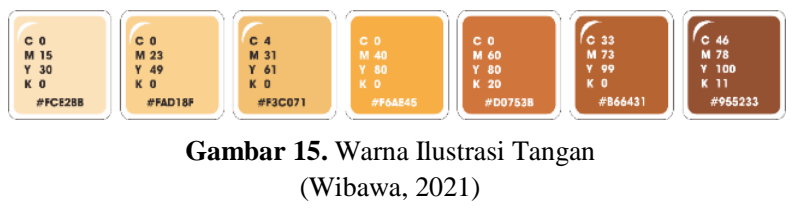

\section{(3). Tipografi}

Jenis tipografi yang digunakan untuk konsep buku "Komunikasi dalam Isyarat" adalah sans serif, serta memiliki tingkat keterbacaan yang jelas. Font sans serif yang dipilih perancang memiliki kesan tegas, modern, namun tetap fleksibel, sesuai karakter anak usia $7-12$ tahun sehingga mampu menarik perhatian anak. Buku "komunikasi dalam Isyarat" memiliki 3 font, diantaranya:

\section{a. Playkidz Font}

\section{A B C DEF GHIJKLMNODQRS T UVWXZ 1234567890}

Gambar 16. Font Playkidz dari situs dafont.com (Figuree Studio, 2019)

b. KG She Persisted Font

\section{ABCDEFGHIJKLMNOPQRSTUVWXZ abcdefghijklmnopqrstuvw xyz 1234567890}

Gambar 17. Font $\mathrm{Kg}$ She Persisted dari dafont.com (Geswein, 2017) 


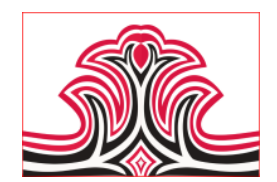

c. Kid Knowledges 1

ABCDEFGHIJKLMNOPORSTUVWXZ

$a b c d e f g h i j k I m n o p Q r s t u v w \times y z$

1234567890

Gambar 18. Font Kid Knowledges 1 dari situs dafont.com (38 lineart, 2019)

\section{(4). Gaya Ilustrasi}

Ilustrasi yang ada di dalam buku "Komunikasi dalam Isyarat" memiliki 2 sifat, yaitu bersifat fungsional dan bersifat estetik (Novitasari, 2018). Ilustrasi yang bersifat fungsional ditunjukkan adanya materi pengenalan huruf hijaiyah baik bahasa isyarat maupun isyarat hijaiyah pada tiap halaman buku yang digunakan anak tunarungu belajar. ilustrasi yang bersifat estetik ditujukan ilustrasi salju berjatuhan yang menumpuk ketika telah jatuh ke daratan, ilustrasi ini selain digunakan sebagai background materi, ilustrasi Salju memiliki makna kemurnian, kesejukan dan keceriaan dan harapan. Ilustrasi turunnya salju menggambarkan sebuah harapan munculnya mediamedia pembelajaran agama Islam lainnya khusus tunarungu agar lebih mudah belajar memahami agama Islam.

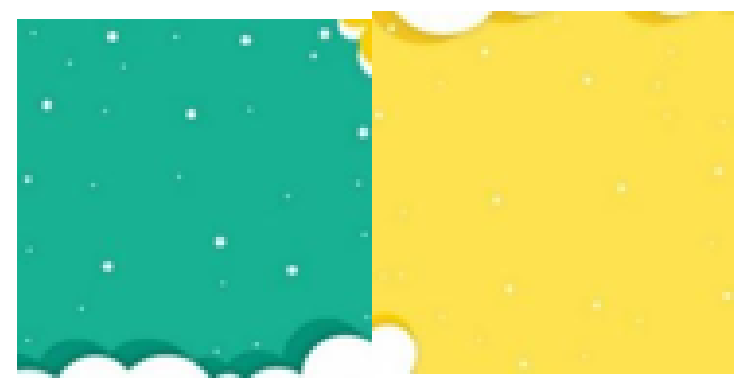

Gambar 19. Ilustrasi Bersifat Estetik (Wibawa, 2021)

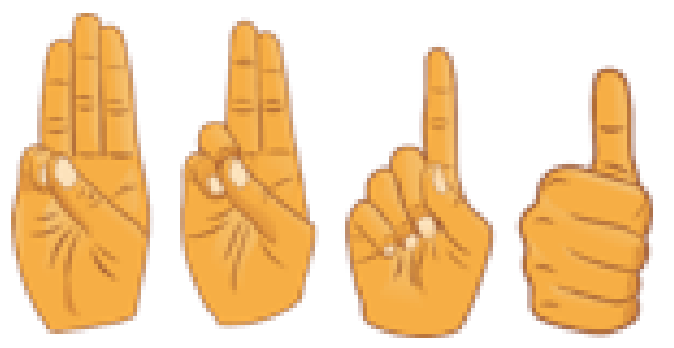

Gambar 20. Ilustrasi Bersifat Fungsional (Wibawa, 2021)
Gorga : Jurnal Seni Rupa

Volume 10 Nomor 01 Januari-Juni 2021

p-ISSN: 2301-5942 | e-ISSN: 2580-2380

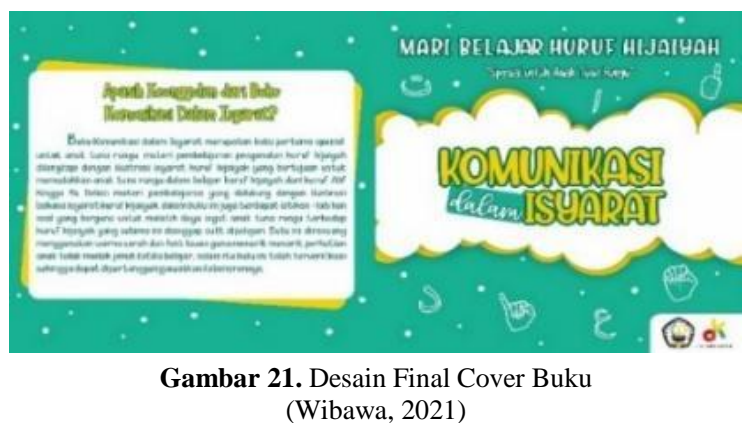

Cover depan terdapat judul buku yaitu Komunikasi dalam Isyarat, dengan highlight "Komunikasi dalam Isyarat", dan tagline "spesial untuk anak tunarungu". Cover belakang berisi kalimat kelebihan buku "Komunikasi dalam Isyarat".

\section{(2). Materi Pengenalan Huruf Hijaiyah}

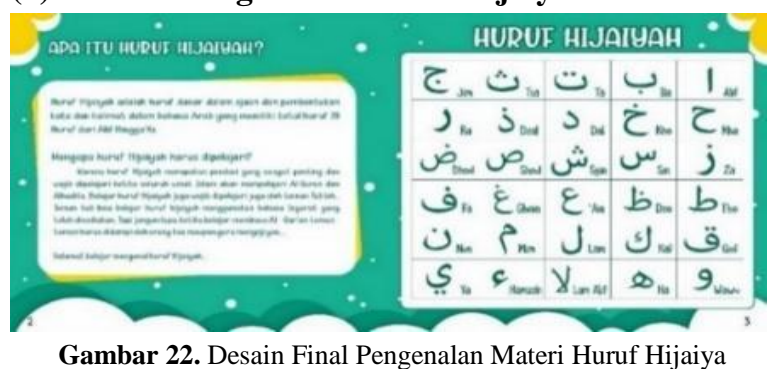
(Wibawa, 2021)

Halaman 2 berisi tentang pengertian huruf hijaiyah dengan menggunakan Bahasa sederhana agar pembaca dapat memahami dengan mudah. Penjelasan lainnya yaitu menjelaskan fungsi belajar mengenal huruf hijaiyah, serta mengingatkan pula kepada pembaca bahwa ketika belajar huruf Hijaiyah harus didampingi orang tua maupun guru mengaji yang telah paham dibidangnya. Halaman 3 berisi huruf hijaiyah dari Alif hingga Ya yang disertai dengan huruf abjad masingmasing huruf hijaiyah.

\section{2). Hasil Perancangan (1). Cover Buku}




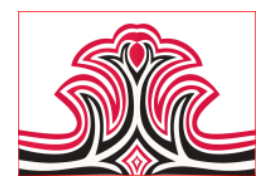

(3). Panduan Mengerjakan Soal

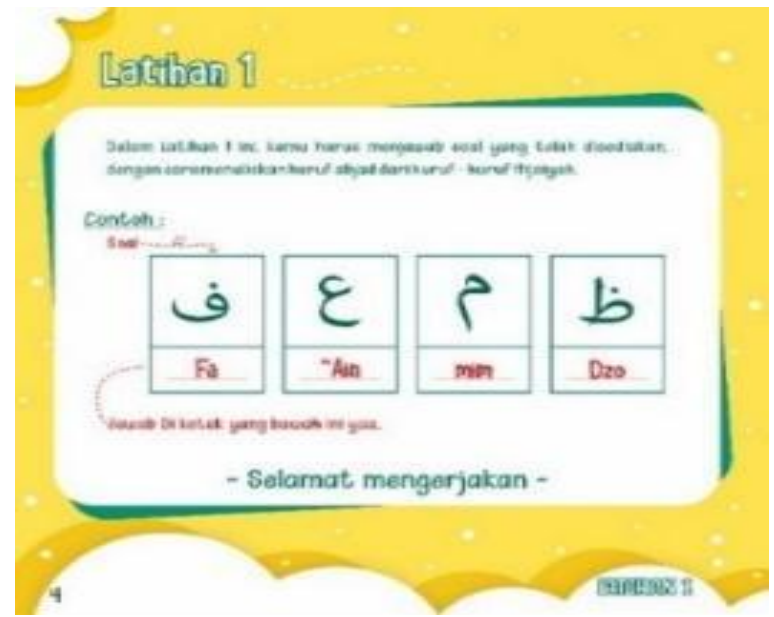

Gambar 23. Desain Final Panduan Mengerjakan Soal (Wibawa, 2021)

Panduan mengerjakan soal dirancang untuk memandu pembaca cara mengerjakan latihan soal yang ada dalam buku "Komunikasi dalam isyarat" dengan tepat dan benar.

\section{(4). Latihan Soal}

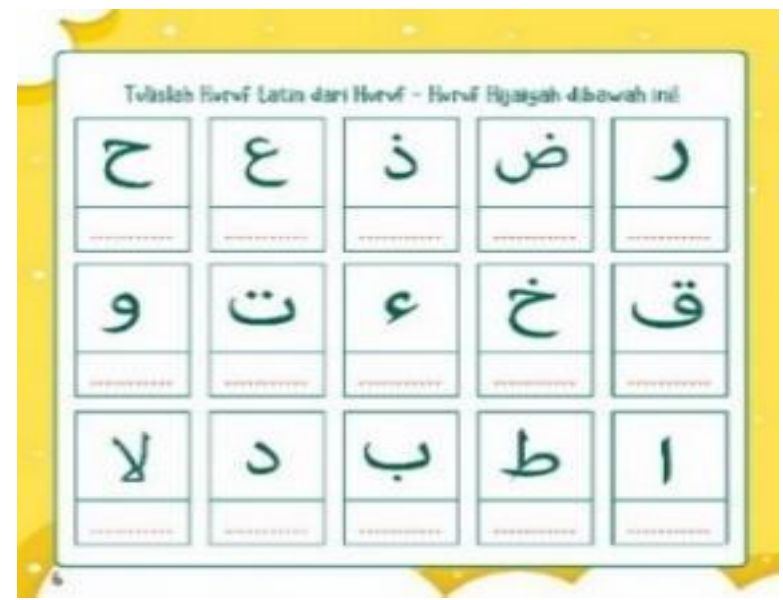

Gambar 24. Desain Final Latihan Soal

(Wibawa, 2021)

Latihan soal dirancang untuk melatih serta menguji pengetahuan pembaca setelah mempelajari materi sebelumnya. Pembaca dituntut harus menjawab dengan benar sesuai yang telah ada pada panduan Latihan.
Gorga : Jurnal Seni Rupa

Volume 10 Nomor 01 Januari-Juni 2021 p-ISSN: 2301-5942 | e-ISSN: 2580-2380

(5). Jeda

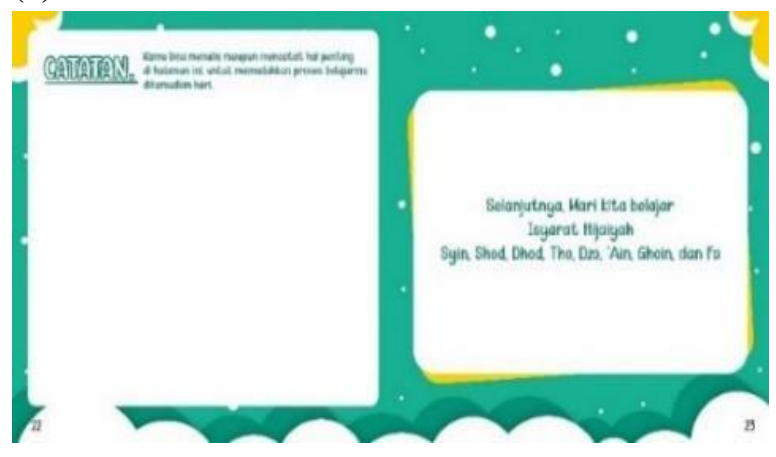

Gambar 25. Desain Final Halaman Jeda (Wibawa, 2021)

Halaman jeda dirancang menjadi sebuah sarana tempat mencatat hal-hal penting maupun menggambar sesuatu untuk pembaca, selain itu halaman jeda juga dirancang sebagai pembatas antara halaman soal pembelajaran dengan halaman materi selanjutnya.

\section{(6). Materi Isyarat Hijaiyah}

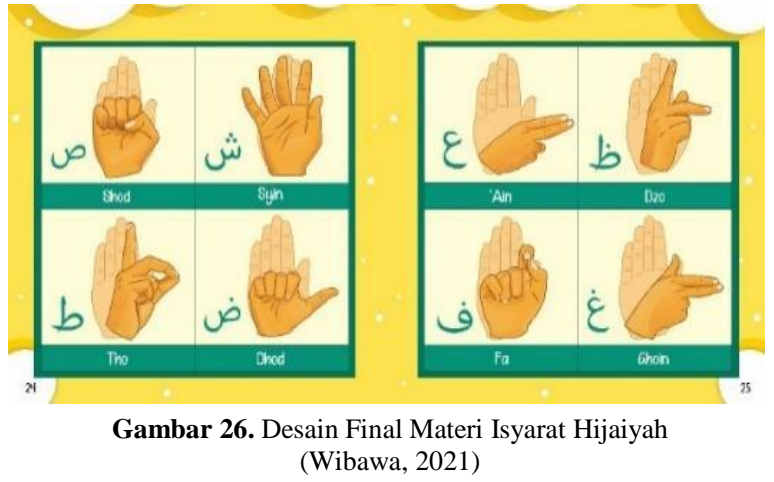

Materi bahasa isyarat huruf hijaiyah terbagi menjadi 8 halaman, satu halaman memuat 4 isyarat huruf hijaiyah agar terlihat detail masing-masing lekukan gerakan tangan huruf hijaiyah. 


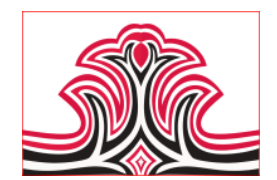

\section{(7). Halaman Evaluasi}

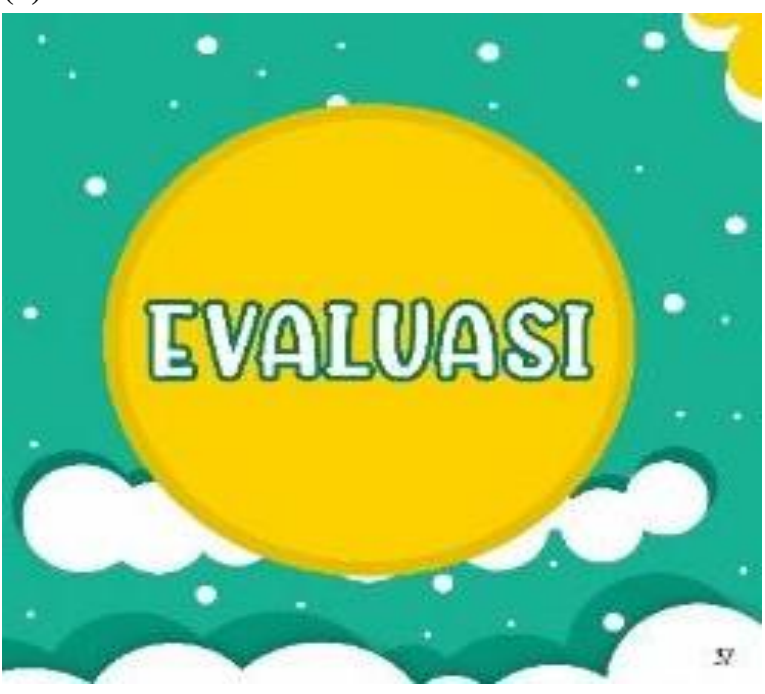

Gambar 27. Desain Final Halaman Evaluasi (Wibawa, 2021)

Halaman evaluasi memiliki beberapa 4 soal evaluasi yang berbeda-beda. Bab evaluasi ini dirancang untuk menguji pengetahuan anak tunarungu setelah mempelajari materi yang ada didalam buku "komunikasi dalam isyarat".

\section{(8). Evaluasi 1.4}

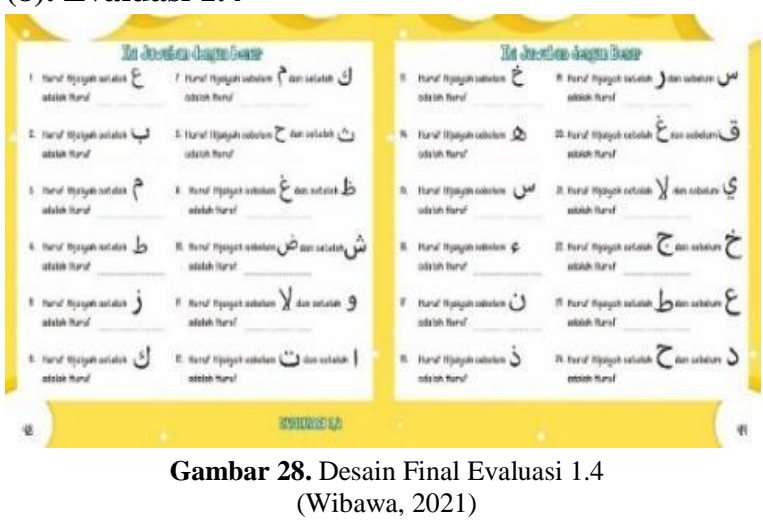

Evaluasi 1.4 merupakan salah satu soal dari bab evaluasi. Evaluasi 1.4 akan menguji pengetahuan pengetahuan pembaca setelah mempelajaru huruf hijaiyah dengan model soal isian, selain itu pembaca juga harus menjawab soal ini dengan tepat dan benar.
Gorga : Jurnal Seni Rupa

Volume 10 Nomor 01 Januari-Juni 2021 p-ISSN: 2301-5942 | e-ISSN: 2580-2380

\section{(9). Halaman Penutup dan Biodata penulis}

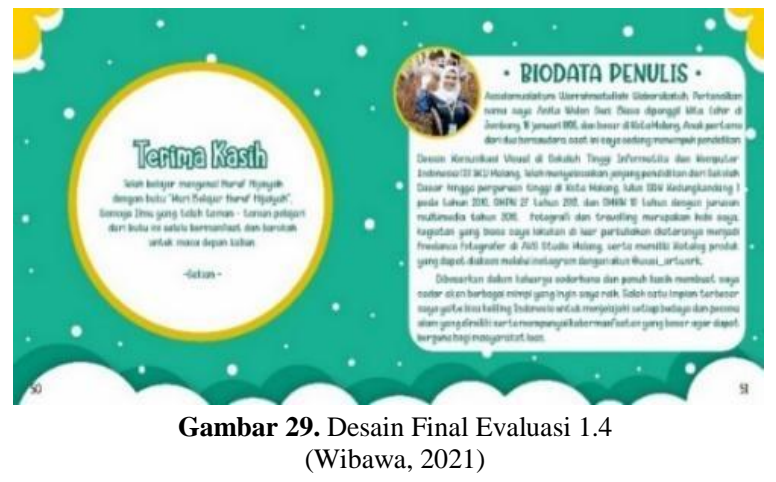

Halaman terakhir pada buku "komunikasi dalam isyarat" yaitu halaman penutup yang berisi ucapan terima kasih kepada pembaca yang telah belajar isyarat hijaiyah menggunakan buku ini, serta biodata penulis berisi tentang riwayat pendidikan, harapan buku ini kedepan, serta cita-cita penulis di masa depan.

\section{3). Implementasi}

\section{(1). Media Utama}

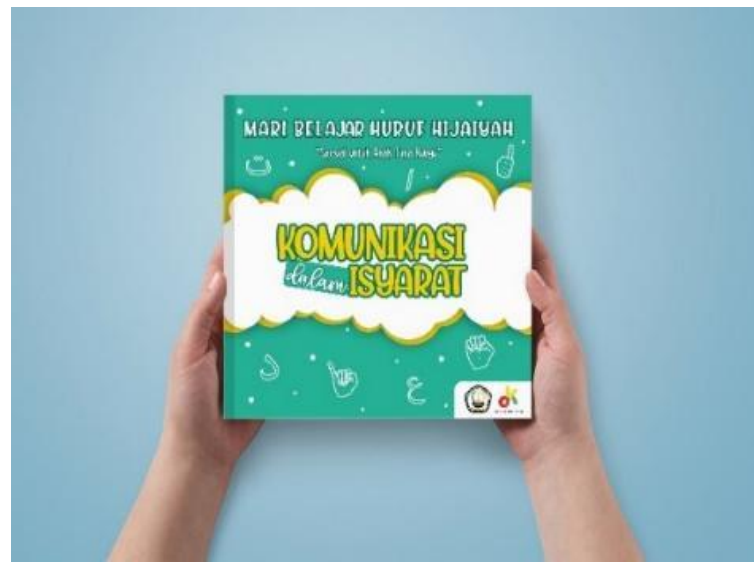

Gambar 30. Desain Final Media Utama (Wibawa, 2021)

Media utama hasil perancangan buku ilustrasi pengenalan huruf hijaiyah untuk anak tunarungu adalah buku penunjang pembelajaran berjudul "Komunikasi dalam Isyarat" berukuran 20x20 cm, soft cover, dan berisi 52 halaman.

\section{(2). Media Pendukung}

\section{a. Puzzle}

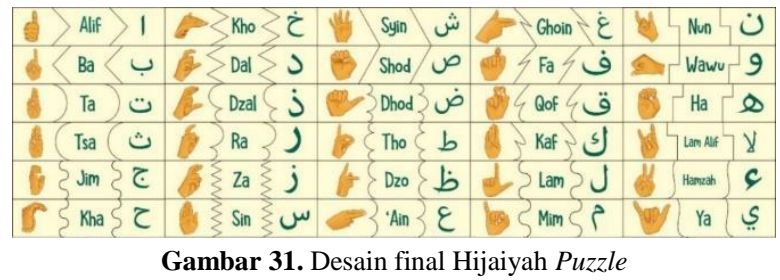
(Wibawa, 2021) 


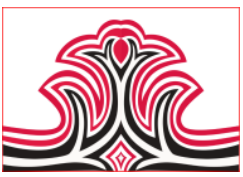

Hijaiyah puzzle dijadikan media pendukung buku "Komunikasi dalam Isyarat" karena dapat digunakan sebagai media bermain sambil belajar. Anak tunarungu harus menyusun kepingan - kepingan puzzle yang memuat huruf hijaiyah, huruf abjad, dan Bahasa isyarat hijaiyah dengan benar. Masing-masing kepingan puzzle memiliki pola bentuk potongan yang berbeda, perbedaan pola potongan akan membantu anak tunarungu menyesuaikan kepingan puzzle sampai benar. Puzzle ini diletakkan pada halaman terakhir buku ilustrasi pengenalan huruf hijaiyah.

\section{b. Poster}

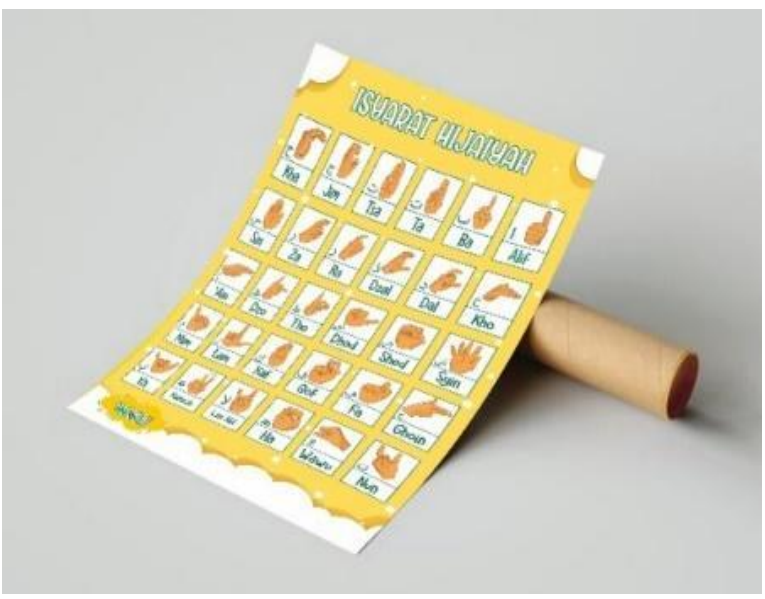

Gambar 32. Desain Final Poster Huruf Isyarat Hijaiyah (Wibawa, 2021)

Poster isyarat hijaiyah dapat ditempelkan pada tembok kelas tunarungu maupun pada dinding kamar anak tunarungu agar dapat dipelajari suatu saat serta dapat meningkatkan daya ingat anak saat belajar huruf hijaiyah melalui bahasa isyarat.

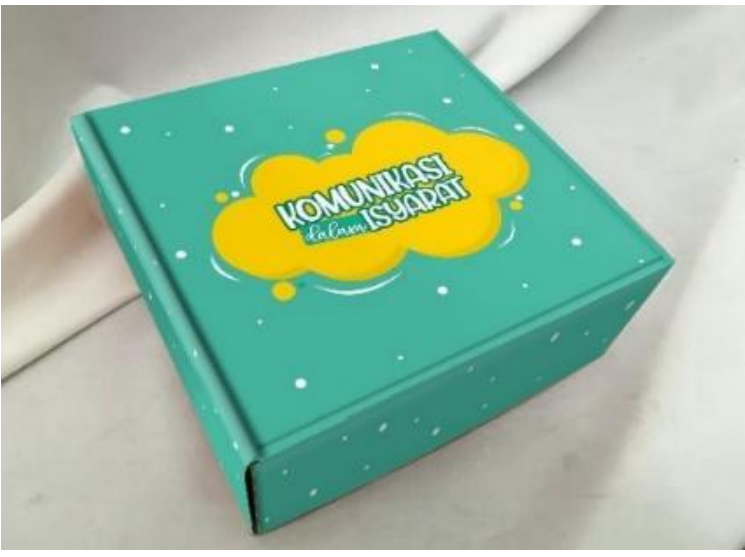

Gambar 33. Desain Final Kotak Kemasan

(Wibawa, 2021)

Kotak kemasan pada media pendukung digunakan untuk mengemas buku "Komunikasi dalam Isyarat", memo, notebook, pembatas buku, dan merchandise
Gorga : Jurnal Seni Rupa

Volume 10 Nomor 01 Januari-Juni 2021

p-ISSN: 2301-5942 | e-ISSN: 2580-2380

menjadi satu kemasan, sehingga terlihat lebih simple dan rapi.

\section{(3). Media Promosi}

\section{a. Standing Banner}
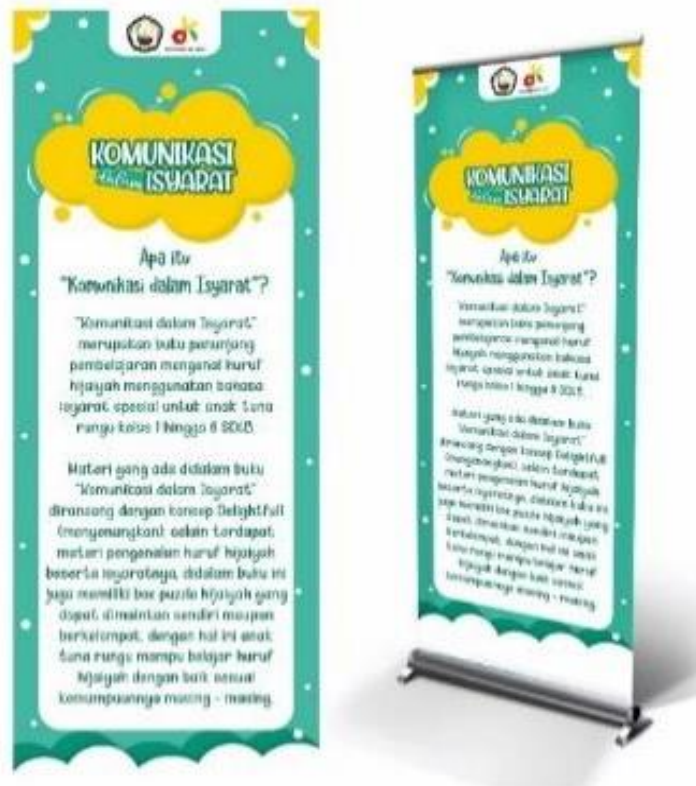

Gambar 34. Desain Final Standing Banner (Wibawa, 2021)

Standing banner digunakan sebagai media promosi offline ketika buku sedang dipromosikan dalam sebuah pameran maupun dijual dibeberapa book store.

\section{b. Kanal Media}
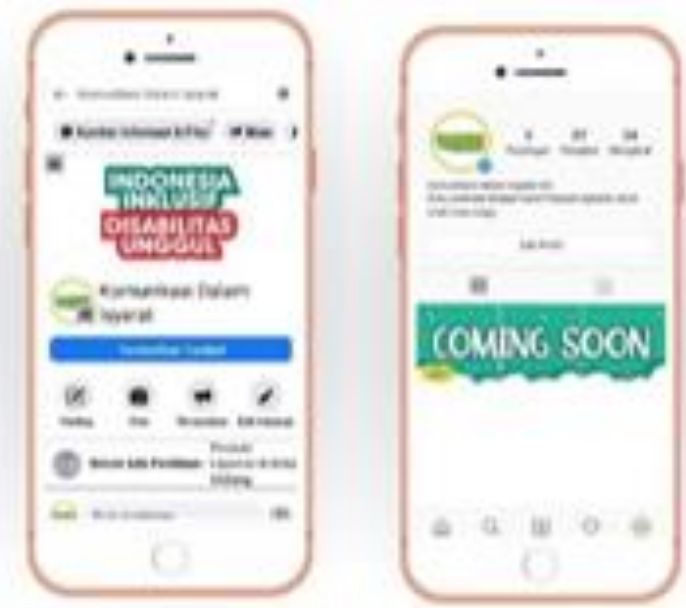

Gambar 35. Desain Final Kanal Media (Wibawa, 2021)

Kanal media yang digunakan untuk mempromosikan buku "komunikasi dalam isyarat" via online adalah Instagram dan facebook fans page. Kedua sosial media ini dipilih karena mayoritas orang tua maupun wali dari 


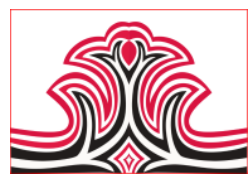

anak tunarungu berusia sekitar 30 tahun, yang masih aktif menggunakan kedua sosial media ini. Akun Instagram bernama @komunikasidalamisyarat, dan facebook fans page bernama komunikasi dalam isyarat.

\section{c. Uji Coba}

Uji coba buku "Komunikasi dalam Isyarat" kepada siswa SD tunarungu di SLB A, B, D Kedungkandang Malang tidak dapat dilaksanakan karena kendala Covid-19 yang sedang mewabah. Ibu Rusmiati selaku Guru mata pelajaran Agama murid tunarungu juga melarang perancang melakukan uji coba dengan cara mendatangi beberapa rumah anak tunarungu karena kondisi anak tunarungu yang masih anak-anak sangat rentan terkena virus. Alasan tersebut menjadikan alasan perancang melakukan uji coba kepada salah satu siswa normal yang mengenyam pendidikan di salah satu Sekolah Dasar Negeri di daerah kelurahan Lesanpuro kecamatan Kedungkandang, berikut hasil screenshot video kegiatan uji coba buku "Komunikasi dalam Isyarat".

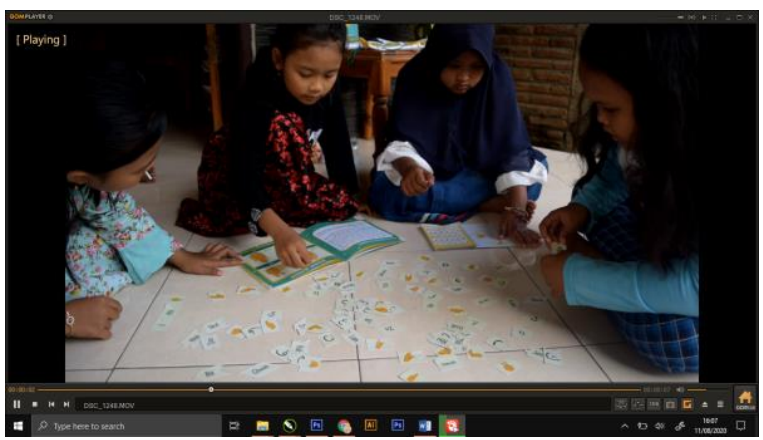

Gambar 36. Uji Coba Menyusun Puzzle dan Mengamati Ilustrasi Isyarat Hijaiyah

(Wibawa, 2021)

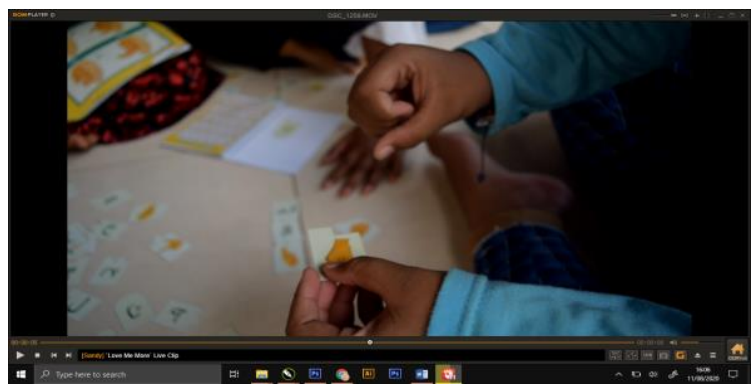

Gambar 37. Uji Coba Meragakan Isyarat Hijaiyah (Wibawa, 2021)
Gorga : Jurnal Seni Rupa

Volume 10 Nomor 01 Januari-Juni 2021

p-ISSN: 2301-5942 | e-ISSN: 2580-2380

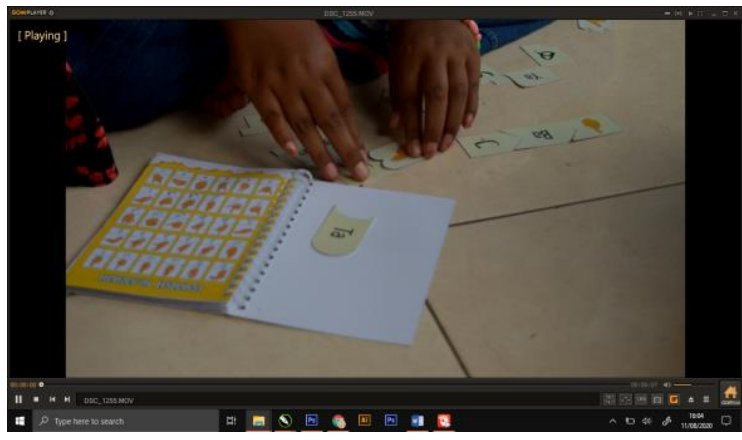

Gambar 38. Uji Coba Menyusun Puzzle

(Wibawa, 2021)

\section{Pembahasan}

Kegiatan perancangan pada dasarnya merupakan sebuah aktivitas untuk memberikan solusi terhadap permasalahan yang dihadapi. Dalam dunia desain komunikasi visual, maka permasalahan komunikasilah yang menjadi fokus utama. Buku sendiri merupakan salah satu media untuk berkomunikasi. Buku ilustrasi pengenalan huruf hijaiyah ini merupakan media yang secara spesifik dirancang untuk memberikan kemudahan bagi anak penyandang tunarungu untuk belajar membaca Al-Quran. Artinya buku ini dirancang dan ditawarkan untuk menjadi sebuah solusi permasalahan pembelajaran Al-Quran bagi anak tunarungu.

Buku yang dilengkapi dengan aktivitas pendukung belajar huruf hijaiyah secara mandiri ini pada dasarnya disiapkan untuk dapat digunakan oleh anak tunarungu secara mandiri. Artinya anak penderita tunarungu tidak harus didampingi oleh guru di sekolahnya. Anak penderita tunarungu dapat mempelajarinya di rumah hanya dengan pendampingan dari orang tua.

Hal ini dimungkinkan karena buku dirancang sangat informatif, dan memuat langkah-langkah yang dapat dengan mudah diikuti oleh siapapun melalui media ilustrasi. Ilustrasi yang digunakan dalam buku ini merupakan ilustrasi yang diciptakan untuk kebutuhan kebutuhan pembelajaran dan bukan hanya bersifat estetis saja. Artinya ilustrasi yang diciptakan di dalam buku ini bersifat fungsional. Ilustrasi sebagai salah satu media seni rupa juga seringkali dimanfaatkan pada berbagai kegiatan pembelajaran dan memang terbukti bahwa penggunaan ilustrasi mampu memberikan dampak yang positif terhadap daya serap siswa (Rahmawati, 2014). Hal ini terjadi karena satu gambar mampu menyampaikan beragam informasi yang cukup kompleks ketika harus diwujudkan dalam bentuk kalimat tertulis. Di sisi lain gambar ilustrasi akan memberikan pengalaman belajar yang lebih mudah 
bagi siswa khususnya penderita tunarungu pada saat akan menirukan sebuah aktivitas pembelajaran atau langkah-langkah tertentu dibandingkan dengan hanya membaca teks di dalam buku dan atau mengikuti kegiatan pembelajaran tatap muka saja.

\section{KESIMPULAN DAN SARAN}

\section{Kesimpulan}

Perancangan buku ilustrasi pengenalan huruf hijaiyah untuk anak tunarungu berjudul "Komunikasi dalam Isyarat" merupakan buku yang dirancang khusus spesial untuk anak tunarungu kelas 1 - 6 SDLB. Tujuan utama perancangan buku ini adalah membantu memudahkan anak tunarungu belajar membaca AlQur'an terutama huruf hijaiyah sesuai dengan kemampuan yang dimilikinya, yaitu menggunakan bahasa isyarat. Buku "Komunikasi dalam Isyarat" juga memiliki media pendukung berupa puzzle hijaiyah yang berfungsi sebagai media belajar sambil bermain anak tunarungu agar belajar mengenal huruf hijaiyah semakin mudah diingat dan lebih menyenangkan, terdapat beberapa jenis potongan puzzle yaitu huruf dohijaiyah, abjad hijaiyah, dan isyarat hijaiyah. Buku "Komunikasi dalam Isyarat" juga telah divalidasi oleh pondok pesantren Darul A'shom, terdapat beberapa revisi dan masukan untuk perancang buku ini diantaranya, isyarat hijaiyah lam alif dan hamzah tertukar, serta sebaiknya background isyarat hijaiyah dihilangkan agar anak tunarungu tidak kebingungan.

\section{Saran}

Terciptanya buku "Komunikasi dalam Isyarat" ini merupakan harapan yang baik untuk membantu anak tunarungu berproses belajar membaca Al-Qur'an. Kegiatan tatap muka dengan guru pada akhirnya tidak menjadi satu - satunya pendekatan belajar untuk siswa penderita tunarungu ini. Terdapat banyak hal yang dapat dikembangkan dari penelitian ini untuk masa mendatang karena secara umum penelitian ini tidak dirancang secara khusus untuk pembelajaran pada masa pandemi COVID-19. Dunia pendidikan khususnya bagi siswa penderita tunarungu dan berkebutuhan khusus lainnya semakin membutuhkan perhatian lebih. Tentunya inovasi - inovasi media pembelajaran berbasis media digital dapat menjadi sasaran penelitian dan pengembangan selanjutnya. Selain itu perlu juga dipikirkan mengenai pengembangan metode pembelajaran baca tulis Al-Quran bagi siswa penderita tunarungu di masa pandemi COVID-19.

\section{DAFTAR RUJUKAN}

38 Lineart. (2019). Kid Knowledges 1. https://www.dafont.com/kids-knowledge.font
Gorga : Jurnal Seni Rupa

Volume 10 Nomor 01 Januari-Juni 2021

p-ISSN: 2301-5942 | e-ISSN: 2580-2380

(diakses tanggal 09 Juni 2021).

Darulashom. (2020). Bahasa Isyarat Hijaiyah. https://www.facebook.com/ponpesdarulashom/p hotos/a.107301890843658/169103007996879 (diakses tanggal 09 Juni 2021).

Figuree Studio. (2019). Play Kidz. https://www.dafont.com/playkidz.font (diakses tanggal 09 Juni 2021).

Geswein, K. (2017). kg she persisted. https://www.dafont.com/kg-she-persisted.font (diakses tanggal 09 Juni 2021).

Gumelar, G., Hafiar, H., \& Subekti, P. (2018). Bahasa Isyarat Indonesia Sebagai Budaya Tuli Melalui Pemaknaan Anggota Gerakan Untuk Kesejahteraan Tunarungu. NFORMASI: Kajian Ilmu Komunikasi, 48(1), 66-67.

Huda, N. (2019). Aplikasi Bahasa Isyarat Pengenalan Huruf Hijaiyah Bagi Penyandang Disabilitas Tuna Rungu. Jurnal Sisfokom (Sistem Informasi dan Komputer), $\quad 8(1), \quad 1-6$. https://doi.org/10.32736/sisfokom.v8i1.582.

Ikbal, M. (2021). Huruf Hijaiyah: 30 Huruf Arab yang Luar Biasa [PENJELASAN LENGKAP]. hasana.id. https://hasana.id/huruf-hijaiyah/ (diakses tanggal 09 Juni 2021).

Monica, M., \& Luzar, L. C. (2011). Efek Warna dalam Dunia Desain dan Periklanan. Humaniora, 2(2), 1084-1096. https://doi.org/10.21512/humaniora.v2i2.3158.

Novitasari, D. (2018). Kajian Estetika Melalui Bentuk Keseimbangan Ilustrasi Durga Dengan Teknik Sablon Discharge Sederhana. Jurnal Bahasa Rupa, 1(2), 73-80. https://doi.org/10.31598/bahasarupa.v1i2.263.

Rahmawati, A. (2014). Pembelajaran Menggambar Ilustrasi Kartun Siswa Kelas VIII E SMP Negeri 1 Keling Kecamatan Keling Kabupaten Jepara. Eduarts: Jurnal Pendidikan Seni, 3(1), 45-53.

https://doi.org/10.15294/eduart.v3i1.4055.

Sanyoto, S. E. (2006). Metode Perancangan Komunikasi Visual Periklanan.

Dimensi.

Sasongko, M. N., Suyanto, M., \& Kurnaiawan, M. P. (2020). Analisis Kombinasi Warna pada Antarmuka Website Pemerintah Kabupaten Klaten. Jurnal Teknologi Technoscientia, 12(2), 153-158.

Sesdiawan, M. (2013). Perancangan Media Buku PopUp Sebagai Upaya Pencegahan Perilaku Anak Usia 7-12 Tahun Berisiko Obesitas Di Bandung the Design of the Media Book Pop-Up Behavior Prevention Efforts As Thechildren Aged 7-12 Years Are At Risk of Obesity in. e-Proceeding of 
Art \& Design, 2(2), 388-395.

Setywan, D. I., Tolle, H., \& Kharisma, A. P. (2017).

Perancangan Aplikasi Communication Board

Berbasis Android Tablet Sebagai Media

Pembelajaran dan Komunikasi Bagi Anak

Tunarungu. Jurnal Pengembangan Teknologi

Informasi dan Ilmu Komputer, 2(8), 2933-2943.

The Little Hijabi Homeschooling. (2020). Poster

Isyarat

Hijaiyah.

https://www.facebook.com/thelittlehijabi/photos /pcb.1553988721421966/1553988514755320/

(diakses tanggal 09 Juni 2021).

Wibawa, M., \& Suci, A. W. (2021). "Kumpulan Foto dan Gambar Penelitian". Hasil Dokumentasi Pribadi: 26 Februari 2021, STIKI Malang.

Wisnuwardani, D. P. (2019). Ada 4, Kenali Ragam Disabilitas.

Liputan6.Com.

https://m.liputan6.com/disabilitas/read/4126110/

ada-4-kenali-ragam-disabilitas (diakses tanggal 09 Juni 2021). 